\title{
Psychological Determinants of Meta-Linguistic Skills by Pre-School Children
}

Psychologiczne uwarunkowania sprawności metajęzykowej dzieci w wieku przedszkolnym

Keywords: meta-language, meaning, defining

Słowa kluczowe: metajęzyk, znaczenie, definiowanie

\section{Introduction}

This work presents issues connected with children's semantic skills, meta-language and meta-linguistic awareness. The subject of the research included meta-language skills of pre-school children aged 4 and 6 or, to be more precise, psycholinguistic conditionings of acquiring the meanings of words by them. Words from the categories home and family were selected as the closest to pre-school children. The authors collected information on meta-language skills of 4- and 6-year-old children with regard to acquiring meanings of words, presented a correlation between thinking and speech as well as analyzed ways of conceptualizing and profiling notions. There is a close relationship between the conclusions on the psychological and linguistic plane in the context of acquiring word meaning by children or the development of meta-linguistic skills and the interdisciplinary character of speech therapy and encourage to use them in therapy of children with reduced lexical and grammatical skills.

* University of Lodz, Faculty of Philology, Institute of Polish Philology and Logopaedics, Department of Contemporary Polish Language, 171/173 Pomorska street, 90-236 Łódź, e-mail: katarzyna.jachimowska@uni.lodz.pl, ORCID: https://orcid.org/0000-0002-6770-3988.

** University of Lodz, Faculty of Philology, Institute of Polish Philology and Logopaedics, Department of Contemporary Polish Language, 171/173 Pomorska street, 90-236 Łódź, e-mail: p.pawlowska.137@ gmail.com. 
In order to comprehend the gist of children's utterances and meanings given to words by children it is necessary to explore the correlations between speech and thinking as children formulate their utterances to the best of their cognitive abilities, revealing at the same time limitations of their perception. The cognitive development of a child takes place in the course of consecutive changes in the way of thinking: from the sensorimotor period through the preoperational stage and concrete operational stage to formal operational time [after: Strelau, 2000, p. 264]. Children from the analyzed groups are at the stage of cognitive development which coincides with the pre-school age: this is the preoperational stage. It is typical of this period to go beyond the sphere of direct perception, beyond "the here and now". Thinking of kindergarteners, however, is subject to certain limitations such as centration (the child focuses attention only on one feature of the given situation) and egocentrism (manifested through the inability to go beyond one's own point of view).

Acquiring communicative competence by children, including the meaning of words, is a process which is subject to constant improvement. As Johann G. Herder argues "language is action, not a finished work" [after: Grabias, 1997, p. 41]. This activity is multi-faceted, closely determined by thinking processes whose unique character becomes increasingly complex together with reaching higher and higher levels of mental development.

\section{Terminology}

The essence of all communication activities is included in the dichotomy: competences - skills. The communicative competence is realized in the act of dialogue and narrative utterances whereas the language competence is accomplished as part of situational and grammatical skills [after: Grabias, 2014, p. 37]. An important role in realizing language activities is played by the semantic skills which co-form the system skills. This skill represents an ability to distinguish information which springs from the correlation on the line language - thinking - reality [Borowiec, 2001, p. 151]. Constructing the semantic base of the word is accomplished in connection with the freedom of choice as the language user - the child - chooses which features of the given object will become representative of its meaning. The quality and rationality of that choice are conditioned by psychobiological determinants. The signalled dependence of speaking and understanding is a subject of interest of psycholinguistics. "Language psychologists" consider words and thinking to be symbiotic components which condition "our being in the world" [Aitchison, 1991, p. 13]. This symbiosis of cognitive and linguistic processes is reflected in the description of conditions of acquiring and developing speech by Józef Porayski-Pomsta, who argues that the different degree of language proficiency is affected by consolidated capabilities of social and genetic nature which create the child's cognitive skills. These, in turn, decide 
about the "quality" of developing thinking as well as the pace and quality of acquiring the language [Porayski-Pomsta, 1994, p. 58].

Meta-language is closely connected with the ability to explicate meanings born out of a compilation of cognitive and linguistic factors. Meta-language is defined as "the object language used for the description of another language"1 [Polański, 1999, p. 363]. This definition may be considered insufficient in the context of conducted research since it is necessary to undertake certain mental processes for linguistic operations to occur. Grażyna Krasowicz-Kupis even describes "cognitive efforts", defining them as analytical activities and activities controlling language processes [Krasowicz-Kupis, 1999, p. 21]. Hence there is a correlation between meta-language operations and intellectual processes: many researchers argue that meta-language is an integral element of a broader mental category which is referred to as meta-cognition [Krasowicz-Kupis, 1999, p. 28].

Meta-linguistic awareness may be considered to be a kind of mental base of metalanguage ${ }^{2}$. Philip Zimbardo distinguished three levels of meta-linguistic awareness, namely [Zimbardo, 1999, pp. 120-121]:

- the basic level connected with reception and reaction to the given perceptive information;

- the level of reflection using symbolic knowledge; making the language user independent from "the here and now";

- the highest level - self-awareness.

In her article $Z$ dziecięcych refleksji nad językiem Ewa Manasterska-Wiącek argues that in the case of small children it is more justified to use the term "linguistic awareness" rather than "meta-linguistic awareness" which the author associates with the knowledge and use of such terms as word or letter [Manasterska-Wiącek, 2018, p. 286].

In the context of the conducted research meta-linguistic awareness is treated broadly as an ability to go beyond the languaged knowledge resources accumulated in the mind. Due to this awareness the child is able to reflect on the linguistic message and, with the use of cognitive and linguistic tools at its disposal, express its thought concentrated around hierarchicalized features of the object/situation. This activity is realized on the basis of the dichotomy described by John Flavell [after: Kwarciak, 1995, p. 14], namely: know that (independent reflection the basis of which is knowledge) and know how (practical verbal and non-verbal activities).

1 The definitional frame presented in Encyklopedia językoznawstwa ogólnego corresponds to the perspective of linguists, such as Emil Benveniste, a French linguist, who presented meta-language as this kind of language "whose exclusive function is its description" [after: Krasowicz-Kupis, 1999, p. 20]. 2 The issue of meta-linguistic awareness is conceived in a number of ways in the literature. For instance, it was broadly discussed by Bogdan Kwarciak in his book Poczattki i podstawowe mechanizmy świadomości metajęzykowej [1995]. 
This "expression of thought" may be verbalized in the form of a definition being "an explanation of the meaning of a word or phrase" [Drabik et al., 2009, p. 127]. In linguistics there is a distinction between explication and definition. These procedures are distinguished by the fact that in the case of explication the sender takes the direction from the word to the object while the opposite happens in the case of a definition: the direction is from the object to the word [Boniecka, 2001, pp. 159-174]. The developed definitions represent the realization extension of mental processes in progress. One of the phenomena manifested at that time is profiling which is "an [objective] mental operation accomplished by the human mind [...] which is associated with accounting for only part of the features of the given object or phenomenon [...]"3. Conceptualization is an activity which coexists with profiling. As it is argued by Monika Peplińska and Małgorzata Święcicka in the article included in "Studia Pragmalingwistyczne" no. 4, it is identical with the meaning and ways of conceptualizing notions are included in created profiles [Peplińska, Święcicka, 2005, p. 183].

\section{Characteristics of the researched group and research area}

The research was conducted among 51 children aged 4 and 6 from the Municipal Kindergarten No. 125 in Lodz. The group of 4 -year-olds consisted of 26 children while the group of 6-year-olds comprised 25 children. Girls represented 59\% of the kindergarteners taking part in the research, while boys $-41 \%$. The cognitive development of children from the group of 4-year-olds was within the norm. Six children attended individual speech therapy classes. In the group of 6-year-olds six children underwent speech therapy and three took part in pedagogical therapy. The development of one boy was not harmonious and the child was being tested for neurological disorders. The children's families may be described as functioning well. Participatory observations were conducted between November 2018 and February 2019.

\section{Organisation of the examination procedure}

During joint group activities, children were asked questions about the semantic circle of terms family and home. As part of a group interview, each child gave an independent answer to the questions asked. The first stage consisted in proposing introductory games (e.g. listening to a poem linked to the topic or another game initiated

3 Another perspective is proposed by Jerzy Bartmiński. According to him, profiling is an operation of subjective nature: profiles acquire the character of "a concept of an object" rather than "variants of meaning" since while presenting the given notion the person who formulates the definition relies on typical features, at the same time voicing concepts which are common to the given culture and environment (the phenomenon of prototype and stereotype) after: Artowicz, 2005, p. 113. 
by children). Then pre-school children were asked the following questions: "Who is a mother?", "What is a family?", "What is a home?" similarly in both age groups. Children were very active and willing to give answers which often referred to the statements of their peers.

Analyzing kindergarteners' explications, the researchers used the method of proceeding proposed by Monika Wiśniewska-Kin. It consists in confronting a child's statement, containing the concept of a given word, with the dictionary definition 4 [Wiśniewska-Kin, 2016, p. 66]. The authors conducted qualitative analyses of answers to analogous questions, comparing statements of 4 and 6-year-old children. This made it possible to distinguish those semantic features which preschoolers consider to be the basis of the meaning of a given concept, and to see the degree of meta-linguistic efficiency in the comparative material.

\section{Analysis of the material}

The notion of family is defined in the dictionary in the following way: "1. Spouses and children; also: a group of individuals united by a kinship or affinity; 2 . clan [...]".

When four-year-old children were asked "What is a family?", they did not refer to the aspects closely connected with this notion, they focused, in turn, on emotional sensations. This emotional profile seems monothematic and uniform (this is a feature convergent with their stage of cognitive development, namely the preoperational period) as children's utterance are characterized by a high frequency of verbs such as love each other, like each other, smile. Importantly, children's responses did not have formal linguistic definition determinants since definition is a figure characterized by a specified form. There are three main elements, namely the word which is defined (from Latin definiendum), the connector and the part defining the defined word (from Latin definiens).

As opposed to four-year-old children, six-year-olds answering the same question listed members of the family: children's concept of this notion was constructed around kinship in which the profile - being convergent with the dictionary definition - is included. On the one hand, attention is drawn to realizations of full sentences and, on the other, the fact that the answers were attempts to give definitions. Examples included: family is, for instance, your mum, your daddy; grandparents are family, too; cousins are family, too. What is more, six-year-old children revealed their ability to decentralize thinking, being in the late stage of preoperational thinking in accordance with Piaget's theory. They were capable of presenting one-dimensional meta-reflection, expressing a diversity of the meaning of the term family (mentioning, e.g. the deceased). Children often engaged in polemics, paying attention to some

4 The dictionary definitions come from Drabik et al., 2009. 
inaccuracies noticed in utterances of their peers, which clearly indicates meta-linguistic awareness: Patrycja didn't say that, but I want to say that [...]. They did this on the basis of the analysis of utterances heard before and confronting them with their own languaged knowledge resources.

Another defined notion which was subject to analysis is mum. According to the dictionary definition mum is "tenderly about mother", whereas mother is defined as: "1. a woman who has her own child (children); 2. a superior <a nun who performs higher functions in a convent $>$; 3 a female animal in relation to its offspring [...]".

The children were not expected to give all the meanings of the word. It was desirable to make a reference to the first word meaning as the research was profiled in the direction of the semantic field of the word family. Four-year-old children, answering the question "Who is a mother?", did not account in their utterances for aspects which are relevant from the point of view of mature language users, they confined themselves to listing activities associated with the mother. Importantly, these activities are characterized by a large degree of stereotypization. This may be explained by Piaget's theory concerning stages of cognitive development of children. Children gave expression to their limitations in thinking through creating the aforementioned stereotypical profile of mum. When the first child answered the question "Who is a mother?", saying she cleans, then the rest of the kindergarteners, not altering the cognitive trail set by their peer in any way, followed in his footstep, listing a whole range of activities which are associated with mother. According to them, mum is a person who cooks, cleans in the kitchen, washes the floors.

It is also possible to find in children's responses the egocentric tendency to "outshine" the utterances of their peers through attempts to show off. Having the foundations of meta-linguistic awareness, children are able to reflect on such a choice of linguistic means so as to present the given feature in a stronger and more emphatic way in response to the utterance of another child. Four-year-old children are, therefore, capable of using characteristic "meta-language flexibility": participating in a discussion they are able to change the subject of their reflection very quickly, concentrating their cognitive efforts on expressing the intensity of the feature of one activity instead of answering the question (S: my mum cleans, R: and my mum once cleaned for hours, M: and my mum once cleaned all the time).

Unlike four-year-olds, six-year-old children who were asked the question "Who is a mother?" presented definitions (isolating definiendum and definiens), manifesting their higher linguistic proficiency and growing meta-reflection. They replied that mum is a person who has us in her tummy and gives birth to us; mum is such a person who of course can't be a boy and she created us, we were born out of her; mum is a person that we are similar to. They also attempted to assign the notion of mum to a superior category of people: as compared to four-year-old children, six-year-olds displayed a greater ability to categorize. Apart from that, it is worth stressing the syntactic aspect: the utterances are compound-complex sentences. Like in the case of defining the family, the 
children aged six consider the aspect of blood ties to be a relevant component of the notion. It is so important that the concept of the notion mum/mother is built around it.

Children also manifest their ability to hierarchize phenomena and persons. To do so it is necessary to accomplish thinking operations going beyond the limitations of the preoperational stage, such as analysis, comparison and then deduction. Children grow more and more confident heading towards a higher level of cognitive development, trying to draw conclusions. One of the girls, combining two interpretations of her friends mum has more time to play with children and mum takes care of children the most arrived at a conclusion that mum is a person who is more important than dad. This happens with the use of reflection of meta-linguistic character determining the choice and purpose of the means used.

Apart from the semantic field of family the researchers checked in the course of the research the understanding and ways of defining in the area of the semantic category of home. Stownik jezyka polskiego [The Dictionary of the Polish Language] defines home as follows: "1. a building where one lives or a company; 2. an apartment or room in which one lives; 3 . a family, household members, also: a dwelling together with its dwellers [...]".

Each of the above dictionary components of the notion was considered to be semantically relevant and anticipated in the context of the research. As opposed to earlier interpretations included in the answers to the questions about family or mother, in which deficiencies in the content were observed in relation to the dictionary definitions, 4-year-old children presented the aspects of meaning identical as those presented in the dictionary. Children's utterances (something in which people live; something where there are parents and children; something where you can sleep) cannot be classified as full definitions in formal linguistic terms. Certain formal unity should be stressed, however, as most utterances began with the indefinite pronoun "something". Children built their utterances in accordance with the construction which they heard once earlier. This is another example of the occurrence of cognitive limitations in kindergarteners which result in poor vocabulary and stylistic monotony.

It should be analyzed why children answering analogous definitional questions "What is a family?" and "Who is a mother?" failed to account for aspects which are important from the point of view of an adult language user yet answering the question "What is a home?" they listed the expected elements associated with the dictionary interpretation of the meaning. Before children were asked the question, they had listened to a poem by Anna Łada-Grodzicka Dwa domy [Two homes]. It was a form of introduction to the topic of the classes. It is likely that earlier listening to the poem in the group affected the interpretation of four-year-olds ${ }^{5}$ : constructing their

5 After listening to individual lines children were supposed to complete the missing elements on two boards presenting homes. This is one of the fragments of this work: "[...] The first one will be tall, and the other one short. In the big one people live, and in the little one dwarves" (children stick illustrations on the homes - parents with children and dwarves, respectively) - A. Łada-Grodzicka in: Domy, 
utterances, the children were inspired by the content of the poem, revealing the centralized train of thought.

It is interesting to analyze the conceptualization of the notion home in which one of the children accentuated two semantic elements: attributes of the building and family (A home has a chimney and also people and that is all). For the child these two semantic properties represent equal conditions of the meaning of the word home.

Another observed meta-linguistic strategy consisted in focusing on these activities which may be done at home. Children built impersonal constructions with the defective verb "can", e.g. ("What is a home?"): You can watch cartoons on the compute therer; You can watch television; You can play with the owl from Stodziaki [a type of plush toys available in one of Biedronka supermarkets]. Activity verbs (together with the objects) dominated in the semantic network of semantic associations concerning the notion of home: play (with the owl), watch (cartons), watch (television) combining the same meaning element: spending free time in a pleasant way. Children did not enumerate any other activities apart from those which the mature language user associates unambiguously with leisure (preoperational egocentrism).

The egocentricity of four-year-old children's cognitive nature was manifested also in other examples of their statements as they tended to begin their utterances in the first person singular - I have [...], not presenting the description of the notion which they were asked to give but a subjective definition of it.

In response to the definitional question "What is a home?" six-year-old children gave answers which may be formally referred to as definitions since the children distinguished the defined word (home) - definiendum and the defining part united by a connector. On the one hand, definiens was expressed through giving synonymous examples: Home is something, for example, blocks of flats or such normal houses ("normal house" probably in the meaning of "detached house"; a six-year-old child, however, not having an adequate vocabulary range, used its cognitive resources and made a meta-linguistic reflection; its result is regarding a detached "normal" house as a representative example of the given semantic category). On the other hand however, children presented descriptions in which one may see the development of the definiens to an expression identical with the dictionary definition, e.g. Home is something you live in; Home is the family, all together. In the utterances of six-year-old children the concept of the notion home includes the components of meaning regarded as important from the perspective of an adult language user. Importantly, despite the fact that also the group of older children listened to a short poem before the

domki, domeczki - scenariusz zajęć, 2015. Children's answers to the question "What is a home?", such as: Something where dwarves live in their little home, It may be tall or small illustrate the fact that kindergarteners duplicated the contents of the poem. This observation closely correlates with the stage of cognitive development of four-year-old children: uniformity of the selected perspective dominated the content of presented interpretations. 
test $^{6}$, six-year-olds adopted a separate independent scheme of meta-reflection. They did not get inspired by the contents which they heard. This is a symptom of cognitive and linguistic nature indicating that six-year-old children abandon the centralist cognitive track.

Six-year-old children, similarly to four-year-olds, used this meta-language strategy which consisted in describing the notion home through presenting the activities which are performed in it. Nevertheless, unlike in the case of the younger kindergarteners, their semantic associations included activities unrelated to play (We sleep, cook and eat at home; And we wash and lie, too; And we clean, too). Children's explications sometimes compared meanings of two notions, such as home and hotel, e.g. At home you can stoke a furnace, it is warm, there's a radiator, everything is free, you don't have to pay for anything. And, for example, in a hotel you have to pay for everything. We can be at home our whole life and in a hotel you're only for some time. The strategy of contrast enabled children to identify notions in a more expressive manner.

\section{Summary of research results}

The research shows that explications of four-year-old children considerably differ from those of six-year-old children. While utterances of four-year-old children did not meet the criteria to be called definitions from a formal linguistic perspective, utterances of older kindergarteners included the definition components: definiendum, connector and definiens. Their utterances were characterized by a wealth of linguistic means (presentation of examples and comparisons) as well as syntactic skill (from compound sentences to compound-complex sentences). Interpretations of the group of younger children were, in turn, characterized by monothematic nature or formal minimalism. What is more, they showed a tendency to single perspective meta-language reflection and multiplication of the content which they heard from their peers. It turned out that the manifested egocentrism limits the cognitive perspective and determines the choice of meta-language tools.

The qualitative analysis of the material allowed to capture a number of cause and effect relationships. The impact of mental limitations on children's semantic efficiency results in the fact that their semantic skills are not autonomous and children are prone to adopt the meta-reflection scheme which they heard (in a text or an utterance of another child). The phenomenon of "meta-linguistic flexibility" was observed in the course of the research: younger children can easily change the subject of their

6 The content of the rhyming riddle: This is a good place for living / Hide there in heat unforgiving / It has walls, balcony and door / windows, stairs, attic, roof and floor. / You go back there from the playgroup / When mum serves some yummy soup. 
reflection, concentrating on how to outshine another child's utterance rather than how to realize the semantic description.

Meta-linguistic abilities of six-year-old children may be assessed as higher due to increasingly smaller cognitive limitations. More complex thinking processes (e.g. analysis, comparison) determine their use of different meta-linguistic tools. Children also displayed an independent meta-linguistic strategy as their definition representations were not conditioned by the content which they heard before but by their individual experiences and reflections. The compilation of their cognitive tools and increasing meta-linguistic reflection (hierarchizing their knowledge about the world) allows them to produce more complex explications.

It is also necessary to sum up the features of children's meta-language concerning the phenomena of profiling and conceptualization. As it is revealed by the research, conceptualization by four-year-old children is characterized by a considerable axiological element: children construct emotional profiles of notions, but on the other hand they are filled with stereotypization. This phenomenon is a consequence of the preoperational cognitive stage. Conversations conducted with four-year-old children revealed that semantic components from their descriptions do not overlap with dictionary definitions. It is different in the case of older children: six-year-olds presented such descriptions from which emerged the profiles of the notions family, mum, home constructed from features which are relevant from the perspective of a mature language user.

\section{Conclusion}

The conducted research activities allow to conclude that children aged four and six display equally interesting meta-linguistic operations. The qualitative analysis of the collected material made it possible to find answers to questions related to the research problem, i.e. how the definitions of children in the examined age groups differ from each other and what causes these differences. The definitional projections of individual notions are distinct in both analyzed groups (from both strictly semantic and formal linguistic perspective), but also the specificity of mental processes being the foundation of explicated meanings is different. Six-year-old children clearly went beyond Piaget's preoperational stage, showing skill in using formal definition indicators and presenting multi-perspective conceptualizations of phenomena. It is not possible to conclude, though, that six-year-old children fully achieve the stage of concrete operational stage. They manifest, nonetheless, certain cognitive propensity indicating that they have already begun to move to a higher cognitive stage of their development. This clearly translates into their semantic and meta-linguistic skill.

The process of "semantic expressiveness" in children triggered by psychological and linguistic determinants is an issue which is extraordinarily multi-faceted. The 
presented conclusions on the close symbiosis of the mental and linguistic plane in the process of acquiring the meanings of words and the development of meta-linguistic efficiency by children denote the inseparability of these sense-creating generators. It is necessary to account for these correlations also in the context of holistic diagnostic and therapeutic measures.

\section{References}

Aitchison J., 1991, Ssak, który mówi. Wstęp do psycholingwistyki, Warszawa: Państwowe Wydawnictwo Naukowe.

Artowicz I., 2005, Prototyp, stereotyp oraz profile pojęcia "dom" w wypowiedziach młodzieży na podstawie ankiet przeprowadzonych wśród uczniów klas I i II gimnazjum, "Komunikacja i Tekst w Perspektywie Rozwojowej i Dydaktycznej. Studia Pragmalingwistyczne”, no. 4, pp. 113-128.

Boniecka B., 2001, Definicje i eksplikacje dziecięce, [in:] S. Grabias (ed.), Zaburzenia mowy. Mowa. Teoria. Praktyka, Lublin: Wydawnictwo Uniwersytetu Marii Curie-Skłodowskiej, pp. 159-174.

Borowiec H., 2001, Sprawność semantyczna dzieci w wieku przedszkolnym, [in:] S. Grabias (ed.), Zaburzenia mowy. Mowa. Teoria. Praktyka, Lublin: Wydawnictwo Uniwersytetu Marii CurieSkłodowskiej, pp. 151-157.

Domy, domki, domeczki - scenariusz zajęć, 2015, http://www.edukacja.edux.pl/p-26251-domy-dom ki-domeczki-scenariusz-zajec.php (accessed: 20.02.2019).

Drabik L., Kubiak-Sokół A., Sobol E., Wiśniakowska L. (eds.), 2009, Słownik języka polskiego, Warszawa: Wydawnictwo Naukowe PWN.

Grabias S., 1997, Język wachowaniach społecznych, Lublin: Wydawnictwo Uniwersytetu Marii Curie-Skłodowskiej.

Grabias S., 2014, Teoria zaburzeń mowy. Perspektywy badań, typologie zaburzeń, procedury postępowania logopedycznego, [in:] S. Grabias, M. Kurkowski (eds.), Logopedia. Teoria zaburzeń mowy, Lublin: Wydawnictwo Uniwersytetu Marii Curie-Skłodowskiej, pp. 15-71.

Krasowicz-Kupis G., 1999, Rozwój metajęzykowy a osiąnięcia w czytaniu dzieci 6-9-letnich, Lublin: Wydawnictwo Uniwersytetu Marii Curie-Skłodowskiej.

Kwarciak B., 1995, Początki i podstawowe mechanizmy świadomości metajęzykowej, Kraków: Wydawnictwo Uniwersytetu Jagiellońskiego.

Manasterska-Wiącek E., 2018, Z dziecięcych refleksji nad językiem, "Etnolingwistyka", vol. XXX, pp. 285-302.

Peplińska M., Święcicka M., 2005, Sposoby konceptualizacji pojęcia “miłość” w języku dzieci i młodzieży, "Komunikacja i Tekst w Perspektywie Rozwojowej i Dydaktycznej. Studia Pragmalingwistyczne", no. 4, pp. 182-196.

Polański K. (ed.), 1999, Encyklopedia językoznawstwa ogólnego, Wrocław: Wydawnictwo Ossolineum.

Porayski-Pomsta J., 1994, Umiejętności komunikacyjne dzieci w wieku przedszkolnym. Studium psycholingwistyczne, Warszawa: Wydawnictwo Uniwersytetu Warszawskiego.

Strelau J., 2000, Psychologia. Podręcznik akademicki. Podstawy psychologii, vol. I, Gdańsk: Gdańskie Wydawnictwo Psychologiczne.

Wiśniewska-Kin M., 2016, Dziecięce rozumienie świata - w poszukiwaniu uzasadnień postępowania badawczego, "Problemy Wczesnej Edukacji", no. 1(32), pp. 59-70.

Zimbardo P., 1999, Psychologia i życie, Warszawa: Wydawnictwo Naukowe PWN. 


\section{Abstract}

The paper concerns psycholinguistic phenomena connected with meta-language, meta-linguistic awareness and children's semantic skills. The main aim of empirical activities was to analyze psychological and linguistic conditionings of acquiring the meanings of words by 4 - and 6 -year-old children. It was examined how children understand the meaning of words from two categories: home and family. The analyses and conclusions on the creation of meaning presented in the paper are focused around the symbiosis of two planes: cognitive and linguistic. An analysis of the collected empirical material shows that their compilation reveals the unique nature of children's meta-language reflection, the character of concepts and notion profiles which are closely determined by mental processes.

\section{Streszczenie}

Artykuł dotyczy psycholingwistycznych zjawisk związanych z metajęzykiem, świadomością metajęzykową oraz dziecięcą sprawnością semantyczną. Głównym celem działań empirycznych było zgłębienie psychologicznych i językowych uwarunkowań nabywania znaczeń wyrazów przez dzieci 4- i 6-letnie. Sprawdzono, jak dzieci rozumieją znaczenia wyrazów $\mathrm{z}$ dwóch kategorii: dom oraz rodzina. Zaprezentowane $\mathrm{w}$ artykule analizy i wnioski dotyczące kreowania znaczeń pojęć skoncentrowane są wokół symbiozy dwóch płaszczyzn: poznawczej oraz językowej. Analiza zebranego materiału empirycznego wskazała, że dzięki ich kompilacji ujawnia się specyfika dziecięcej refleksji metajęzykowej oraz profili pojęć - ściśle zdeterminowanych przez procesy mentalne. 